\title{
Development and Testing of Techniques to Obtain Infiltration Data for Unconsolidated Surficial Materials, Yucca Mountain Area, Nye County, Nevada
}

By Lon L. Hofmann ${ }^{1}$ (Address Unknown), and William R. Guertal ${ }^{2}$ and Alan L. Flint ${ }^{3}$, U.S. Geological Survey

${ }^{1}$ Foothill Engineering Consultants, Inc., Denver, Colo. (1995), current affiliation unknown 2USGS, Las Vegas, Nev.

${ }^{3}$ USGS, Sacramento, Calif.

U.S. GEOLOGICAL SURVEY

Open-File Report 95-154

Prepared in cooperation with the

U.S. DEPARTMENT OF ENERGY

NEVADA OPERATIONS OFFICE under

Interagency Agreement DE-Al08-97NV12033 


\section{U.S. DEPARTMENT OF THE INTERIOR \\ BRUCE BABBITT, Secretary}

\section{U.S. GEOLOGICAL SURVEY}

Charles G. Groat, Director

The use of firm, trade, and brand names in this report is for identification purposes only and does not constitute endorsement by the U.S. Geological Survey.

For additional information write to:

Chief, Earth Science Investigations Program

Yucca Mountain Project Branch

U.S. Geological Survey

Box 25046, Mail Stop 421

Denver Federal Center

Denver, CO 80225-0046
Copies of this report can be purchased from:

U.S. Geological Survey

Information Services

Box 25286

Federal Center

Denver, CO 80225 


\section{CONTENTS}



\section{FIGURES}

1. Map showing locations of the automated prototype ring infiltrometer experiments

2. Schematic diagram of the automated prototype constant-water-supply head, ring infiltrometers ............................

3-6. Graphs showing:

3. Cumulative-infiltration data and Philip-equation fit obtained near borehole UE-25 UZN \#85, Yucca Mountain, Nevada

4. Cumulative-infiltration data and Philip-equation fit obtained near borehole UE-25 UZN \#14, Yucca Mountain, Nevada.

5. Infiltration-rate data and Philip-equation first derivative fit obtained near borehole UE-25 UZN \#85, Yucca Mountain Nevada.

6. Infiltration-rate data and Philip-equation first derivative fit obtained near borehole UE-25 UZN \#14, Yucca Mountain, Nevada.

\section{TABLES}

1. Volumetric water outflow and pressure transducer calibration data from the prototype-automated-infiltrometer water-supply tank

2. Least-squares linear-regression equations for calibrating data from the water-supply tank and the pressure transducer of the prototype automated infiltrometer....

3. Cumulative-infiltration and infiltration-rate data using the automated prototype infiltrometer.

4. Calculated hydrologic parameters using the Philip two-term equation and corresponding experimentally extrapolated saturated hydraulic conductivity values 


\section{CONVERSION FACTORS}

\begin{tabular}{ccc}
\hline Multiply & By & To Obtain \\
\hline centimeter $(\mathrm{cm})$ & 0.3937 & inch \\
centimeter per hour $(\mathrm{cm} / \mathrm{h})$ & 0.7874 & feet per day \\
gram per cubic centimeter $\left(\mathrm{g} / \mathrm{cm}^{3}\right)$ & 62.428 & pound per cubic foot \\
kilometer $(\mathrm{km})$ & 0.6214 & mile \\
liter $(\mathrm{L})$ & 1.057 & quart \\
meter $(\mathrm{m})$ & 3.281 & foot \\
millimeter $(\mathrm{mm})$ & 0.03937 & inch \\
millivolt $(\mathrm{mV})$ & 0.001 & volt \\
square centimeter $\left(\mathrm{cm}^{2}\right)$ & 0.001076 & square foot \\
\hline
\end{tabular}




\title{
Development and Testing of Techniques to Obłain Infiltration Data for Unconsolidated Surficial Materials, Yucca Mountain Area, Nye County, Nevada
}

\author{
By Lon L. Hofmann, Foothill Engineering Consultants, Inc., (1995) and \\ William R. Guertal and Alan L. Flint, U.S. Geological Survey
}

Abstract

Measurements of surface infiltration at Yucca Mountain, Nevada, a potential site for a high-level nuclear-waste repository, are needed to determine spatial variability of hydrologic properties for a wide variety of skeletal desert soils. This report describes and evaluates existing instruments and methods to measure infiltration capacities and their appropriateness for determining hydrologic properties on Yucca Mountain. The report also presents preliminary infiltration data and estimated measurements of saturated hydraulic conductivity and sorptivity and describes the methods used to collect the data.

A prototype automated, constant watersupply-head, double-ring infiltrometer was developed to measure saturated hydraulic conductivity and provide surface-water-flux data to estimate sorptivity. The infiltrometer consisted of an inner confining ring ( 0.30 to 0.75 -meter inside diameter), an outer confining ring ( 0.6 to 3.5 -meter inside diameter), float switches, solenoid valves, a data logger, and water-supply tanks. The prototype automated infiltrometer was used to measure infiltration rates near boreholes UE-25 UZN \#85 and UE-25 UZN \#14 where large ranges in sorptivity and saturated hydraulic conductivity were expected. The cumulative-infiltration data were fit using the two-term Philip equation from which saturated hydraulic conductivity and sorptivity values were derived. The saturated hydraulic conductivity values at the two sites differed by an order of magnitude. Sorptivity values differed by more than 100 percent between the two sites. Differences in infiltration rates were at ributed to differences in measured physical characteristics and differences in initial water contents of soils at the two borehole sites.

\section{INTRODUCTION}

The U.S. Geological Survey is cond icting investigations to determine the geologic and hydrologic suitability of Yucca Mountain, Nevada, as a potential site for a mined geologic repository for highlevel nuclear wastes. These investigations are being conducted in cooperation with the U.S. Department of Energy, under Interagency Agreement DE-AI0897NV12033, as part of the Yucca Mountain Site Characterization Project (formerly the Nevada Nuclear Waste Storage Investigations Project).

Yucca Mountain consists of a series of ash-flow tuffs that are welded and nonwelded, are variably saturated, and are fractured. Alluvium and other unconsolidated surficial materials overlie most of the tuff (Scott and Castellanos, 1984, p. 7-12). The hydrologic properties of these materials are needed for interpretation of hydrologic data in the unsaturated zone and for input to hydrologic models of Yucca Mountain.

Hydrologic properties, such as saturated hydraulic conductivity $\left(K_{s}\right)$ and sorptivity $(S)$, can be calculated using field-measured flow rates of artificially applied water. Saturated hydraulic conductivity is an important property used in one-dimensional 
(1-D) and two-dimensional (2-D) ground-water-flow submodels and in site-scale three-dimensional (3-D) ground-water-flow models (Wittwer and others, 1992, p. 264-265). Field $K_{s}$ determination involves measuring infiltration rates for an adequate time until an apparent steady-state infiltration rate, which can be interpreted as $K_{s}$, is obtained. Sorptivity, a less commonly used property, is a measure of the capillary uptake of water predominating the early time infiltration process. Sorptivity values are dependent on the initial water content $\left(\theta_{i}\right)$, the water-retention function $[\theta(\psi)]$ where $\psi$ is the water potential, and hydraulic conductivity $(K)$. Sorptivity may be used to determine soil hydraulic properties, such as the hydraulicconductivity function $[K(\theta)]$, and the soil-waterdiffusivity function $[D(\theta)]$ (Clothier and White, 1981, p. 241-242; White and Perroux, 1987, p. 1094; 1989, p. 324). Sorptivity also has been used in inverse modeling to estimate $K(\theta)$ or $[\theta(\psi)]$ (Zimmerman and Bodvarsson, 1989, p. 1423-1426).

\section{Purpose and Scope}

This report describes the evaluation of existing instruments and methods to measure infiltration capacities and their appropriateness for measuring hydrologic properties at Yucca Mountain, the performance of a prototype automated infiltrometer, and the quality of the resulting data for estimating field hydrologic properties from selected areas of Yucca Mountain. The report also describes experiments using the prototype automated infiltrometer to obtain preliminary infiltration data and describes the calculated hydrologic parameters of interest, $K_{S}$ and $S$, derived from these data.

The scope of the report includes infiltrometer data that were collected from March of 1993 to July of 1993 near two borehole locations drilled in unconsolidated alluvial materials on Yucca Mountain (fig. 1). These sites were chosen because of the likelihood of water ponding on the soil surface and their expected differences in infiltration rates. Infiltration data were collected with a prototype constant-water-supply head, ring infiltrometer (hereinafter referred to as the prototype automated infiltrometer), designed to operate effectively with confining rings of greater than 1-m inside diameter (Hofmann and others, 1993). Because the prototype automated infiltrometer needed to be portable, ring sizes were limited to less than 1-m inside diameter so the double-ring system was used for this study. The infiltration runs were conducted over time periods ranging from 4 to 20 hours. These tim: periods were adequate to obtain apparent steady-stc ${ }^{+} \mathrm{e}$ infiltration rates that were extrapolated as the fieldmeasured $K_{s}$ value.

Cumulative-infiltration and infiltration-rate curves were developed with the prototype automated infiltrometer for the two borehole locations. The $S$ and A parameters of the Philip equation were fitted to th cumulative-infiltration and infiltration-rate measurements. Comparison of the field-measured $K_{s}$ to the fitted $A$ parameters was used as a check for the quality of the data.

\section{Definitions and Relations Between Properties}

The following section defines the properties that were used to determine infiltration capacity and hydrologic properties at Yucca Mountain. Relations of measured to calculated values also are discussed.

\section{Infiltration}

Infiltration is the term applied to the process of water entry into the soil, generally by downward flow through all or part of the soil surface (Hillel, 1980, p. 5).

\section{Cumulative Infiltration}

Cumulative infiltration is the summed amount of water that has entered through the soil surface. Cumulative infiltration is calculated as:

$$
I=Q / c
$$

where

$I$ = cumulative infiltration, in centimeters;

$Q=$ volume of water entering the soil surface, in liters; and

$c=$ cross-sectional area of soil surface, in centimeters squared.

This value is usually plotted against time to obtain a cumulative-infiltration curve. Fitting of infiltration equations to cumulative-infiltration curves can be used 


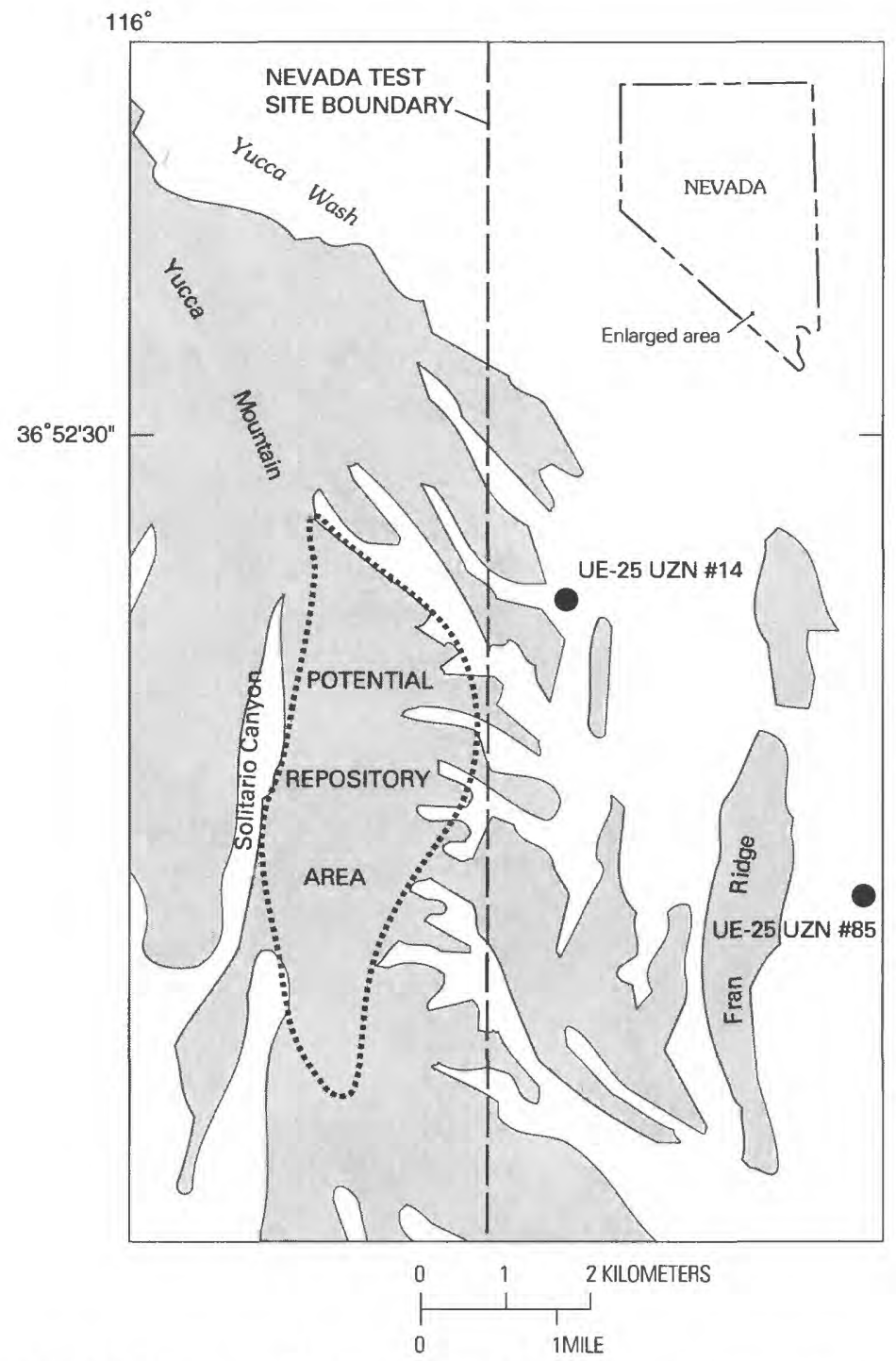

Figure 1. Locations of the automated prototype ring infiltrometer experiments.

to obtain values for hydrologic properties, such as $K_{S}$ and $S$.

\section{Infiltration Rate}

Infiltration rate is the volume of water flowing into the soil per unit soil surface area (Hillel, 1980, p. 6). Infiltration rate and surface flux are essentially analogous. Infiltration rate is calculated as:

$$
i(t)=Q /(c t)
$$

$(t)=$ infiltration rate as a function of time, in centimeters per hour.

\section{Sorptivity}

Sorptivity describes the rate of uptake of water by a porous medium without gravitational effects (Flint and others, 1994, p. 94). Sorptivity depends on both water-supply-head and initial soil-moisture content. Sorptivity is calculated as:

$$
S=I / t^{1 / 2}
$$

where 
where

$S$ = sorptivity, in centimeters per square root of time; and

$t^{1 / 2}=$ square root of time, in hours.

\section{Saturated Hydraulic Conductivity}

Saturated hydraulic conductivity is defined as a proportionality constant that is a measure of the ability of a soil to conduct the flow of water when all pore space is filled with water (Koorevaar and others, 1983, p. 118). Saturated hydraulic conductivity is reported in centimeters per hour. Saturated hydraulic conductivity is extrapolated from the infiltration-rate curve when apparent steady-state infiltration has been achieved.

\section{Philip Equation}

Philip (1957, p. 260-261) developed a physical model to describe 1-D vertical infiltration. The Philip equation in two terms is:

$$
I(t)=S\left(\theta_{i}\right)^{1 / 2}+A t
$$

where

$$
\begin{gathered}
I=\text { cumulative infiltration, in centimeters, as a } \\
\text { function of time; } \\
\theta_{i}=\begin{array}{c}
\text { initial soil-water content in cubic centi- } \\
\text { meters water per cubic centimeters of soil; }
\end{array} \\
\begin{array}{c}
A= \\
\text { a parameter related to vertical hydraulic } \\
\text { conductivity that is long-term, in centi- } \\
\text { meters per hour; and }
\end{array} \\
t=\text { time, in hours. }
\end{gathered}
$$

The differential form of equation 4 , or the infiltration rate, is:

$$
i(t)=(1 / 2) S\left(\theta_{i}\right) t^{-1 / 2}+A
$$

The usefulness of the Philip equation for infiltration prediction can be assessed by comparing $K_{S}$, extrapolated from apparent steady-state infiltration rates, with the fitted Philip $A$ parameter. Theoretical and experimental analyses indicated that the value of $A$ is between $0.3 K_{s}$ and $0.6 K_{s}$ (Youngs, 1968, p. 159; Talsma, 1969, p. 274; Talsma and Parlange, 1972, p. 144; Swartzendruber and Youngs, 1974, p. 165). Because $S$ is a function of water-supply head and of $\theta_{i}$, a series of infiltration measurements made at a zero water-supply head over a range in $\theta_{i}$ yields $S(\theta)$. Estimation of infiltration can be obtained once an $S(\theta)$ curve and range in $A$ values are experimentally determined for a representative area (Chong and Green, 1979, p. 92-94; Sharma and others, 1980, p. 110-118).

\section{EVALUATION OF EXISTING INFILTROMETERS}

Several of the infiltrometers were evaluated for their legitimate and practical use for field hydrologic measurements at Yucca Mountain and were recognized as being legitimate instruments to measure hydrologic flow properties (Bouwer, 1986, p. 835843; Green and others, 1986, p. 775-796). Evaluation criteria were (1) the ability to measure a representative elementary surface area (RESA); (2) the ability to test soils that have different surface characteristics; the ability to measure on slopes; (3) the ability to characterize only near-surface material; (4) the ability to conform to boundary conditions and assumptions of the method of analysis; and (5) the portability, durability, and ease of use. One of the primary constraints in the evaluation process was the physical nature of the unconsolidated materials at Yucca Mountain. Schmidt and others (1992) conducted a preliminary study measuring physical properties of unconsolidated materials that were delineated into four main geologiclithologic-qualifier units. Schmidt and others (1992) reported that cobble count and percent slope were two of the most important factors limiting the type of infiltrometers that could be used. Volumetric rock-fragment contents (grain sizes greater than $2 \mathrm{~mm}$ ) ranged from 20 to 60 percent, and 2 to 46 percent were classified as cobbles (grain sizes greater than $76 \mathrm{~mm}$ ), which quantified most of the unconsolidated materials as skeletal (U.S. Soil Conservation Service, 1975, p. 383-384). Percent slope ranged from 0 to 71 percent.

Infiltrometers can be classified into two basic groups: subsurface and surface (Amoozegar and Warrick, 1986, p. 735-770; Elrick and Reynolds, 1992, p. 1-25). Subsurface infiltrometers measure 3-D flow across the boundaries of a symmetrical borehole at a specific depth of interest. The main restriction of subsurface infiltrometers is the requirement of maintaining a symmetrical borehole throughout the measurement. Surface infiltrometers measure 1-D and 
2-D flow and can be designed to measure a wide range of RESA's. Surface infiltrometers also can be designed for either ponded infiltration or infiltration under tension measurements. The major limitations of surface infiltrometers is a greater likelihood of surface disturbance that can adversely affect surface-flow properties and the inability to determine directly the effects of subsurface restrictive layers (Amoozegar and Warrick, 1986, p. 735-770; Elrick and Reynolds, 1992, p. 1-25). The skeletal nature of the unconsolidated materials at Yucca Mountain makes subsurface infiltrometers unusable, and areas where slopes are greater than 3 percent makes some surface-ponding infiltrometers unusable.

\section{Shallow Borehole Permeameter}

The shallow borehole permeameter is a subsurface infiltrometer which can be used to measure $K_{s}$ from the near soil surface to a depth exceeding a few meters (Amoozegar and Warrick, 1986; p. 758-759). This infiltrometer provides a constant head of water in an uncased borehole of small radius. One of the most critical assumptions for using any kind of borehole infiltrometer is that borehole symmetry needs to be maintained during the measurement. An uncased, symmetrical borehole is practically impossible to maintain in the unconsolidated material of Yucca Mountain because of the predominantly skeletal makeup of the material. Shallow depths to bedrock or large rocks frequently exist in the unconsolidated material, limiting borehole depths. Calculation of hydrologic properties using a shallow borehole permeameter is much more complex than using other infiltrometers because of the 3-D flow characteristics around a shallow borehole. Because of these limitations, all shallow borehole infiltrometers and techniques were considered inadequate for field hydrologic-property determination at Yucca Mountain.

\section{Air-Entry Permeameter}

Bouwer (1966, p. 729-738) developed an airentry permeameter to measure $K_{S}$ using a large watersupply head, air-entry value, and Darcy's law. The permeameter consists of a metal cylinder which may be placed on the soil surface or within a hole dug into the soil. The metal cylinder is carefully driven about $10 \mathrm{~cm}$ into the soil, making sure there is no creation of a gap between the soil and cylinder wall because the permeameter must be operated as a closed system. Depth of $K_{s}$ measurement is the depth to which the bottom edge of the cylinder is driven into the soil. After the infiltration rate, air-entry pressure, and depth of wetting-front are measured, the hydraulic conductivity $(K)$ is calculated using a solution of Darcy's equation. The conditions under the cylinder during infiltration pertain to sorption, so $K_{s}$ is suggested to be 2 times the calculated $K$ value (Bouwer, 1966; p. 732737).

Due to the coarse, skeletal nature of the unconsolidated material being measured, it is very difficult to obtain proper placement of the cylinder so that the infiltrometer works as a closed system. Fu thermore, placement of a cylinder below $10 \mathrm{~cm}$ would be very difficult while minimizing surface disturbance. Therefore, the infiltrometer was assumed to be unsuitable for hydrologic measurements at Yucca Mc'untain because of difficulties with setting up the infiltrometer properly and the limitation of the depth at which $K_{s}$ can be measured.

\section{Tension Infiltrometer}

The tension infiltrometer can be used to measure hydrologic properties under a positive water-supply head (ponded conditions) or under a negat ve-pressure (tension) water-supply-head (Perroux and White, 1988, p. 1206-1211). A hollow disk covered with a permeable membrane is placed on the soil surface. The disk is connected to a water reservoir to masure the volume of water entering the soil through the disk. Water passes through the permeable membrane into the soil under a positive or negative pressure regulated by the infiltrometer. The volume of water entering the soil through the membrane-covered disk is measured as a function of time. Hydraulic conductivity and $S$ can be calculated using the measured infiltrometer values as a function of initial soil-water cc ntent or soil-water tension (Chong and others, 1982, p. 228229; Green and others, 1986, p. 793-796; White and Perroux, 1989, p. 324-328; Logsdon and Jaynes, 1993, p. 1426-1429).

Advantages of tension infiltrometers are the range in water-supply potentials at which measurements can be taken and their portability. A borehole permeameter is currently (1994) being modified for use as a tension infiltrometer that will function on the 
sloping surfaces of Yucca Mountain. A disadvantage of tension infiltrometers is the likelihood of surface disturbances. The permeameter will not function properly if there is not good contact between the membrane-covered disk and the surface of the material. In many places, rock cover would have to be removed or a contact sand layer, our both, would be needed between the membrane-covered disk and the material surface, which could potentially alter the true surface-flow properties. Another disadvantage is that the RESA is limited to the size of the membranecovered disk, usually around $0.20 \mathrm{~m}$ in diameter. Prototype testing is needed to check the adequacy of this tension infiltrometer once it is completed.

\section{Sprinkler-Imposed Steady-Flux Infiltrometer}

A sprinkler application of water provides a means of controlling surface flux until a steady-state flow rate in the unconsolidated material is obtained. The $K$ at a selected steady flux is determined by the flux divided by the gradient in hydraulic head over the depth interval of interest (Green and others, 1986, p. 789). Sprinkler application is useful for determining $K$ at soil-water contents close to saturation. Advantages of sprinkler infiltrometers are the flexibility to inchude various sizes of RESA's. Sprinkler application more closely simulates the physical processes of rainfall infiltration, and the systems can be effectively used on sloping surfaces, which is a major limitation of most other types of infiltrometers.

The major disadvantages of sprinkler infiltrometers are the complexity of their design and the logistics of operating them. First, a plot frame is needed to confine the area of measurement for runoff collection. The runoff collection and measurement is needed for mass-balance calculations. Second, an even water application is needed that, in turn, needs a controlled water-pressure source, which often is inaccessible in the field. This type of infiltrometer should not be used on soils containing layers that are relatively impervious to water flow within the profile which could impede vertical-water flow and thus introduce error in the assumed vertical flux (Green and others, 1986, p. 790).

Advantages of the sprinkler infiltrometer are such that it is practical to use under circumstances that limit the other infiltrometers, but further development and prototype testing of a sprinkler-infiltrometer system that is usable on Yucca Mountain are needed. To obtain an understanding of the range in selected hydrologic properties at Yucca Mountain, an immediate priority was set to develop a much simpler and versatile ring infiltrometer.

\section{Ring Infiltrometer}

A ring infiltrometer consists of a circular confining ring in which the water-supply-head is a minimum height of ponded water within the confining ring that is maintained at a constant level. Infiltration measurements are made by measuring the amount $\mathrm{c} f$ water entering the soil surface in the ring as a function of time (commonly referred to as ponded infiltration). Infiltration measurements using a single large confining ring or smaller double-rings is an approach that can be used to measure cumulative infiltration (Green and others, 1986, p. 791-793). Ponded areas larger than $1.2 \mathrm{~m}$ would maximize the likelihood of 1-D flow measurements using a single confining ring (Bouwer, 1986, p. 830-831). Double-ring infiltrometers, where a larger ring is placed around a smaller ring concentrically, have been used to limit lateral divergence of water infiltrating in the inner ring that has an inside diameter less than $1.2 \mathrm{~m}$. Cumulative-infiltration and infiltration-rate measurements are used to calculate $K_{s}$ and $S$ (Young, 1968, p. 159-160; Talsma, 1969, p. 270-275; Talsma and Parlange, 1972, p. 146149; Green and others, 1986, p. 791-793).

The ring infiltrometer is one of the most versatile types of infiltrometers that can be used for measuring hydrologic properties under ponded conditions. Infiltrometer ring sizes can be adjusted to inchude practically any size RESA. Most double-ring infiltrometers are relatively portable. A disadvantage. of ring infiltrometers is that some degree of surface disturbance is likely when placing the rings into the ground, especially in skeletal materials. Double-ringinfittrometer ponding studies also are limited to areas with less than 3 percent slope. Differences in ponderhead height across the surface area of the infiltrometer rings on sloping surfaces greater than 3 percent could induce deviations from 1-D vertical flow.

An already developed ring infiltrometer was easily automated and was made capable of measuring infiltration rates with a high degree of accuracy. The prototype automated infiltrometer consists of an inner and outer ring, magnetic-reed switch-float sensors, 
solenoid valves, data logger, and water-supply tanks (fig. 2). Mechanical operation of the infiltrometer is the same despite the size of the confining ring. The depth of water-supply head is maintained by two magnetic-reed switch-float sensors. When the watersupply-head level reaches a minimum height, one of the float sensors sends a pulse signal to a data logger that opens an electronic solenoid valve, allowing water to flow into the confining infiltrometer ring, by gravity, from the supply tank. Once the water-supply head reaches a preset maximum depth, the other float sensor sends a pulse to the data logger that closes the solenoid valve. Ten seconds after the solenoid valve shuts off, the data logger reads and records the pressure transducer output along with the corresponding time. It is these time readings that are used to calculate infiltration rates. These time intervals range from 0 to 30 minutes depending on the infiltration rates.

Water is supplied to each ring individually by a cylindrical 210-L tank fitted with a pressure transducer that has been calibrated to measure cumulative water outflow. Calibration of the pressure transducer with the water-supply tank involves release of water from the supply tank at known volumes. For each incremental release of water from the supply tank, a corresponding pressure-transducer reading is made. This pressure-transducer reading represents the change in supply-tank water height because a known volume of water has been released. This calibration also accounts for physical changes in supply-tank dimensions.
The pressure transducer is calibrated to the water-supply tank using a least-squares equation:

$$
P T=a+b(q)
$$

where

$$
\begin{gathered}
P T=\text { the pressure-transducer reading, in miltivolts; } \\
a=\text { the initial pressure transducer reading before } \\
\text { release of water from the suroly tank; that } \\
\text { is, when } \mathrm{q}=0 ; \\
b=\text { the least-squares slope relation of supply-tank } \\
\text { volume-outflow change per change in } \\
\text { pressure transducer reading; and } \\
q=\text { cumulative volume water outflow from the } \\
\text { supply-tank, in liters. }
\end{gathered}
$$

The calibration equation is rearranged tc calculate cumulative volume of water flow into the prototype automated infiltrometer confining rings, in hiters:

$$
q=(P T-a) / b
$$

Dividing the cumulative volume outflow of water by the surface area of the confining ring results in cumulative infiltration:

$$
I=q / c
$$

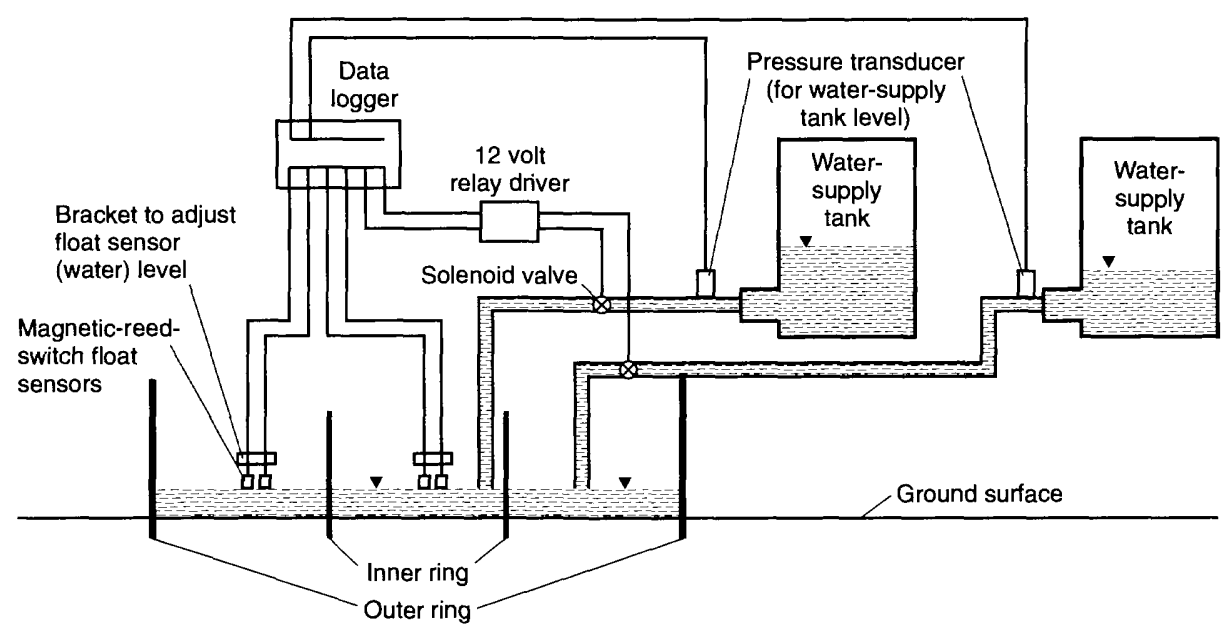

Figure 2. Automated prototype constant-water-supply head, ring infiltrometers. 
where

$I$ = cumulative infiltration, in centimeters; and

$c=$ the cross-sectional area of the soil surface, in centimeters squared.

To obtain the infiltration rate, cumulative infiltration is divided by the time step at which the pressure transducer was read. Thus, infiltration rate is calculated by:

$$
i=I / t
$$

where

$i=$ infiltration rate, in centimeters per unit time; and

$t$ = time, in hours.

\section{EXPERIMENTAL RESULTS}

\section{Locations and Procedures}

The prototype automated infiltrometer was installed in two locations at Yucca Mountain: in Pagany Wash near borehole UE-25 UZN \#14 (N14), and on a stable terrace adjacent to Fortymile Wash at borehole UE-25 UZN \#85 (N85) (fig. 1). A smallscale version of the prototype automated infiltrometer was used near N14, consisting of an inner confining ring that had a $0.30-\mathrm{m}$ inside diameter surrounded by an outer ring that had a $0.64-\mathrm{m}$ inside diameter. A large-scale version was used at N85 consisting of an outer ring that had a $3.5-\mathrm{m}$ inside diameter and three inner rings having $0.75-\mathrm{m}$ inside diameters that were spaced $1 \mathrm{~m}$ apart. The inner rings of the large-scale infiltrometer were considered to be independent replications of the ponded-infiltration experiment. Surface slope was less than 3 percent at both locations. The bottom edge of the confining ring was implanted below the soil surface at a minimum depth of $0.15 \mathrm{~m}$ to ensure 1-D vertical flow of infiltrating water.

Cumulative-infiltration and infiltration-rate curves were developed from the data obtained with both types of prototype automated infiltrometers using equations 7, 8, and 9. Equations 4 and 5 were fit to the developed infiltration curves by means of the leastsquares technique to obtain values for the $S$ and $A$ parameters. Measured $K_{s}$ values were compared to 30 to 60 percent of parameter $A$. The parameters of equations 4 and 5 are physically based; therefore, differences in experimental results would be expected to be related to physical properties, such as pore-size dist ${ }^{-i}$ bution and porosity. Bulk density and porosity of representative samples collected in the area of the tivo boreholes were measured.

\section{Operation of Prototype Automated Infiltrometer}

Water-supply-tank calibration data are listed in table 1. Least-squares linear regression calibration equations, derived from the data presented in table 1 , for the prototype automated infiltrometers are listed in table 2. The calibration equations in table 2 are based on equation 6. Water-supply-tank-measurement acc'iracies ranged from 0.083 to $0.131 \mathrm{~L}$ at one standard deviation between the three supply tanks used. For an infiltrometer ring that had a $1-\mathrm{m}$ inside diameter, this range in calibration variability would result in an error of 0.03 to $0.05 \mathrm{~cm}$ of infiltrated water at ar $\alpha$ $=0.025$, where $(1-\alpha)$ is the confidence coefficient.

The prototype automated infiltrometer performed well with minimal man-hour input. A constant depth of ponded water was maintained over the soil surface at a minimum ponding depth of $1.0 \mathrm{~cm}, 0.1 \mathrm{~cm}$ during the infiltration experiments. Once the prototype automated infiltrometer was operating, refilling the water-supply tank and data collertion from the data logger were the only requirements to conduct the experiments.

\section{Infiltration-Capacity Measurements}

Cumulative-infiltration curves were successfully constructed for both sampling washes at Yucca Mountain using data from the prototype automated infiltrometer and equation 8. Cumulative-infiltration rates (fig. 3) measured by two of the three inner confining rings were similar at the N85 location. Data used to construct the curves in figure 3 are listed in table 3. Reliable data from the third inner ring could not be collected because the pressure transducer for the water-supply tank failed; only results from the two inner rings are presented in figure 3 and table 3 . Earlytime infiltration was very similar for both rings, but the 
Table 1. Volumetric water outflow and pressure transducer calibration data from the prototype-automated-infiltrc meter water-supply tank

[All cumulative volume-outflow measurements in liters; all pressure-transducer readings in millivolts]

\begin{tabular}{|c|c|c|c|c|c|}
\hline \multicolumn{2}{|c|}{ Tank 1} & \multicolumn{2}{|c|}{ Tank 2} & \multicolumn{2}{|c|}{ Tank 3} \\
\hline $\begin{array}{c}\text { Cumulative } \\
\text { volume outflow }\end{array}$ & $\begin{array}{l}\text { Pressure outflow } \\
\text { reading }\end{array}$ & $\begin{array}{c}\text { Cumulative } \\
\text { volume outflow }\end{array}$ & $\begin{array}{l}\text { Pressure outflow } \\
\text { reading }\end{array}$ & $\begin{array}{c}\text { Cumulative } \\
\text { volume outflow }\end{array}$ & $\begin{array}{l}\text { Pressur? outflow } \\
\text { reating }\end{array}$ \\
\hline 0.0 & -0.501 & 0.0 & -0.414 & 0.0 & 0.690 \\
\hline 2.0 & -0.503 & 2.0 & -0.415 & 2.0 & 0.688 \\
\hline 4.0 & -0.504 & 4.0 & -0.417 & 4.1 & 0.687 \\
\hline 6.0 & -0.506 & 6.0 & -0.418 & 6.1 & 0.685 \\
\hline 8.0 & -0.508 & 8.0 & -0.420 & 8.1 & 0.683 \\
\hline 10.0 & -0.509 & 10.1 & -0.421 & 10.1 & 0.681 \\
\hline 12.0 & -0.511 & 12.1 & -0.423 & 12.1 & 0.679 \\
\hline 14.0 & -0.513 & 14.0 & -0.425 & 14.1 & 0.678 \\
\hline 16.0 & -0.515 & 16.0 & -0.427 & 16.1 & 0.676 \\
\hline 18.0 & -0.516 & 18.0 & -0.428 & 18.2 & 0.673 \\
\hline 20.0 & -0.518 & 20.0 & -0.430 & 20.2 & 0.672 \\
\hline 22.0 & -0.520 & 22.1 & -0.432 & 22.2 & 0.670 \\
\hline 24.0 & -0.522 & 24.1 & -0.434 & 24.2 & 0.668 \\
\hline 26.1 & -0.523 & 26.1 & -0.435 & 26.2 & 0.666 \\
\hline 28.1 & -0.525 & 28.1 & -0.437 & 28.2 & 0.664 \\
\hline 30.1 & -0.527 & 30.0 & -0.439 & 30.2 & 0.662 \\
\hline 32.1 & -0.529 & 32.1 & -0.440 & 32.2 & 0.660 \\
\hline 34.1 & -0.530 & 34.1 & -0.442 & 34.3 & 0.658 \\
\hline 36.1 & -0.532 & 36.1 & -0.444 & 36.3 & 0.656 \\
\hline 38.1 & -0.534 & 38.1 & -0.445 & 38.3 & 0.655 \\
\hline 40.1 & -0.536 & 40.1 & -0.447 & 40.3 & 0.653 \\
\hline 42.1 & -0.537 & 42.1 & -0.448 & 42.3 & 0.651 \\
\hline 44.1 & -0.539 & 44.1 & -0.450 & 44.3 & 0.649 \\
\hline 46.1 & -0.541 & 46.1 & -0.452 & 46.3 & 0.647 \\
\hline 48.1 & -0.543 & 48.1 & -0.453 & 48.3 & 0.645 \\
\hline 50.1 & -0.544 & 50.1 & -0.455 & 50.3 & 0.643 \\
\hline 52.1 & -0.546 & 52.1 & -0.457 & 52.3 & 0.641 \\
\hline 54.1 & -0.548 & 54.1 & -0.459 & 54.3 & 0.639 \\
\hline 56.1 & -0.550 & 56.1 & -0.460 & 56.4 & 0.638 \\
\hline 58.1 & -0.551 & 58.1 & -0.462 & 58.4 & 0.636 \\
\hline 60.1 & -0.553 & 60.1 & -0.464 & 60.4 & 0.634 \\
\hline 62.1 & -0.555 & 62.1 & -0.465 & 62.4 & 0.632 \\
\hline 64.1 & -0.557 & 64.1 & -0.467 & 64.4 & 0.630 \\
\hline 66.2 & -0.558 & 66.1 & -0.469 & 66.4 & 0.628 \\
\hline 68.2 & -0.560 & 68.1 & -0.470 & 68.4 & 0.627 \\
\hline
\end{tabular}


Table 1. Volumetric water outflow and pressure transducer calibration data from the prototype-automated-infiltrometer water-supply tank-Continued

[All cumulative volume-outflow measurements in liters; all pressure-transducer readings in millivolts]

\begin{tabular}{|c|c|c|c|c|c|}
\hline \multicolumn{2}{|c|}{ Tank 1} & \multicolumn{2}{|c|}{ Tank 2} & \multicolumn{2}{|c|}{ Tank 3} \\
\hline $\begin{array}{c}\text { Cumulative } \\
\text { volume outflow }\end{array}$ & $\begin{array}{l}\text { Pressure outflow } \\
\text { reading }\end{array}$ & $\begin{array}{c}\text { Cumulative } \\
\text { volume outflow }\end{array}$ & $\begin{array}{l}\text { Pressure outflow } \\
\text { reading }\end{array}$ & $\begin{array}{c}\text { Cumulative } \\
\text { volume outflow }\end{array}$ & $\begin{array}{l}\text { Pressure outflo'v } \\
\text { reading }\end{array}$ \\
\hline 70.2 & -0.562 & 70.1 & -0.472 & 70.4 & 0.625 \\
\hline 72.2 & -0.564 & 72.1 & -0.474 & 72.4 & 0.623 \\
\hline 74.2 & -0.566 & 74.1 & -0.475 & 74.4 & 0.621 \\
\hline 76.2 & -0.567 & 76.1 & -0.477 & 76.4 & 0.619 \\
\hline 78.2 & -0.569 & 78.1 & -0.479 & 78.4 & 0.617 \\
\hline 80.2 & -0.571 & 80.1 & -0.480 & 80.5 & 0.615 \\
\hline 82.2 & -0.573 & 82.1 & -0.482 & 82.4 & 0.613 \\
\hline 84.3 & -0.574 & 84.1 & -0.484 & 84.4 & 0.612 \\
\hline 86.3 & -0.576 & 86.2 & -0.485 & 86.4 & 0.610 \\
\hline 88.3 & -0.578 & 88.2 & -0.487 & 88.4 & 0.608 \\
\hline 90.3 & -0.580 & 90.2 & -0.489 & 90.4 & 0.606 \\
\hline 92.3 & -0.581 & 92.2 & -0.490 & 92.5 & 0.604 \\
\hline 94.2 & -0.583 & 94.2 & -0.492 & 94.5 & 0.602 \\
\hline 96.3 & -0.585 & 96.2 & -0.494 & 96.5 & 0.601 \\
\hline 98.3 & -0.587 & 98.2 & -0.495 & 98.5 & 0.599 \\
\hline 100.3 & -0.588 & 100.3 & -0.497 & 100.5 & 0.597 \\
\hline 102.3 & -0.590 & 102.3 & -0.499 & 102.5 & 0.595 \\
\hline 104.3 & -0.592 & 104.3 & -0.501 & 104.5 & 0.593 \\
\hline 106.3 & -0.594 & 106.3 & -0.502 & 106.5 & 0.591 \\
\hline 108.3 & -0.595 & 108.2 & -0.504 & 108.5 & 0.589 \\
\hline 110.3 & -0.597 & 110.2 & -0.506 & 110.6 & 0.588 \\
\hline 112.3 & -0.599 & 112.2 & -0.507 & 112.6 & 0.586 \\
\hline 114.3 & -0.601 & 114.3 & -0.509 & 114.6 & 0.584 \\
\hline 116.3 & -0.603 & 116.3 & -0.511 & 116.6 & 0.582 \\
\hline 118.3 & -0.604 & 118.3 & -0.512 & 118.6 & 0.580 \\
\hline 120.3 & -0.606 & 120.3 & -0.514 & 120.6 & 0.578 \\
\hline 122.3 & -0.608 & 122.3 & -0.516 & 122.6 & 0.576 \\
\hline 124.3 & -0.610 & 124.3 & -0.517 & 124.6 & 0.575 \\
\hline 126.3 & -0.611 & 126.3 & -0.519 & 126.6 & 0.573 \\
\hline 128.4 & -0.613 & 128.3 & -0.521 & 128.6 & 0.571 \\
\hline 130.4 & -0.615 & 130.3 & -0.522 & 130.6 & 0.569 \\
\hline 132.4 & -0.617 & 132.3 & -0.524 & 132.5 & 0.567 \\
\hline 134.4 & -0.618 & 134.3 & -0.526 & 134.6 & 0.565 \\
\hline 136.4 & -0.620 & 136.3 & -0.527 & 136.5 & 0.564 \\
\hline 138.4 & -0.622 & 138.3 & -0.529 & 138.6 & 0.562 \\
\hline 140.4 & -0.624 & 140.3 & -0.531 & 140.6 & 0.560 \\
\hline
\end{tabular}


Table 1. Volumetric water outflow and pressure transducer calibration data from the prototype-automated-infiltrometer water-supply tank-Continued

[All cumulative volume-outflow measurements in liters; all pressure-transducer readings in millivolts]

\begin{tabular}{|c|c|c|c|c|c|}
\hline \multicolumn{2}{|c|}{ Tank 1} & \multicolumn{2}{|c|}{ Tank 2} & \multicolumn{2}{|c|}{ Tank 3} \\
\hline $\begin{array}{c}\text { Cumulative } \\
\text { volume outflow }\end{array}$ & $\begin{array}{l}\text { Pressure outflow } \\
\text { reading }\end{array}$ & $\begin{array}{c}\text { Cumulative } \\
\text { volume outflow }\end{array}$ & $\begin{array}{l}\text { Pressure outflow } \\
\text { reading }\end{array}$ & $\begin{array}{c}\text { Cumulative } \\
\text { volume outflow }\end{array}$ & $\begin{array}{l}\text { Pressure outflow } \\
\text { re`ding }\end{array}$ \\
\hline 142.4 & -0.625 & 142.3 & -0.532 & 142.6 & 0.558 \\
\hline 144.4 & -0.627 & 144.3 & -0.534 & 144.6 & 0.556 \\
\hline 146.4 & -0.629 & 146.3 & -0.536 & 146.6 & 0.554 \\
\hline 148.4 & -0.631 & 148.4 & -0.538 & 148.6 & 0.552 \\
\hline 150.4 & -0.632 & 150.4 & -0.539 & 150.6 & 0.551 \\
\hline 152.4 & -0.634 & 152.4 & -0.541 & 152.6 & 0.549 \\
\hline 154.4 & -0.636 & 154.4 & -0.543 & 154.6 & 0.547 \\
\hline 156.4 & -0.638 & 156.4 & -0.544 & 156.6 & 0.545 \\
\hline 158.4 & -0.639 & 158.4 & -0.546 & 158.6 & 0.543 \\
\hline 160.4 & -0.641 & 160.4 & -0.548 & 160.6 & 0.541 \\
\hline 162.4 & -0.643 & 162.4 & -0.549 & 162.6 & 0.540 \\
\hline 164.4 & -0.645 & 164.4 & -0.551 & 164.6 & 0.538 \\
\hline 166.4 & -0.646 & 166.4 & -0.553 & 166.6 & 0.536 \\
\hline 168.4 & -0.648 & 168.4 & -0.554 & 168.7 & 0.534 \\
\hline 170.4 & -0.650 & 170.4 & -0.556 & 170.7 & 0.532 \\
\hline 172.4 & -0.652 & 172.5 & -0.558 & 172.7 & 0.530 \\
\hline 174.4 & -0.653 & 174.5 & -0.559 & 174.7 & 0.529 \\
\hline 176.4 & -0.655 & 176.5 & -0.561 & & \\
\hline \multirow[t]{2}{*}{178.4} & -0.657 & 178.5 & -0.562 & & \\
\hline & & 180.5 & -0.564 & & \\
\hline
\end{tabular}

Table 2. Least-squares linear-regression equations for calibrating data from the water-supply tank and the pressure transducer of the prototype automated infiltrometer (data are in table 1)

[The $\mathrm{x}$ regression variable is supply-tank cumulative-volume outflow and the $\mathrm{y}$ regression variable is pressure-transducer reading]

\begin{tabular}{cccc}
\hline Tank & $\begin{array}{c}\text { Least-squares linear- } \\
\text { regression equation }\end{array}$ & $\begin{array}{c}\text { Coefficient of } \\
\text { determination } \\
\mathbf{r}^{2}\end{array}$ & $\begin{array}{c}\text { Standard error } \\
\text { of estlmate } \\
\text { (millivolts) }\end{array}$ \\
\hline 1 & $\mathrm{y}=-0.50065-0.00088(\mathrm{x})$ & 1.000 & 0.00007 \\
2 & $\mathrm{y}=-0.41331-0.00084(\mathrm{x})$ & 1.000 & 0.00011 \\
3 & $\mathrm{y}=0.69012-0.00093(\mathrm{x})$ & 1.000 & 0.00026 \\
\hline
\end{tabular}


curves began to diverge after about 5 hours of infiltration. Sorptivity predominates early-time infiltration processes, whereas gravity gradually becomes the predominating force as the depth of the infiltrating wetting front increases. Spatial variability in subsurface restrictive layers to water flow could account for the divergence between the infiltration curves during the long-term infiltration process. These results support the assumption that the $S$ values between the two rings were similar, whereas greater variability occurred between the $A$ parameters.

A cumulative-infiltration curve (fig. 4) was constructed using data (table 3 ) obtained from the small-scale infiltrometer in Pagany Wash near borehole N14. Infiltration rates were larger near the N 14 location than at the N85 location (table 3). Eighty centimeters of water had infiltrated near N14 after 4 hours compared to $10 \mathrm{~cm}$ of water at the N85 location (figs. 3 and 4). Evaporation losses from infiltrating water were a concern during the experiments, but maximum potential infiltration losses did not exceed $0.5 \mathrm{~cm}$ at either location for the duration of the infil'ration runs, which accounted for less than 1 percent $\mathrm{cf}$ the total infiltrated water.

The least-squares technique was used to fit the Philip equation to the cumulative-infiltration data from the two infiltrometer rings at the N85 location (fig. 3) and to the data from the N14 location (fig. 4). Sorptivity values for the two infiltrometer rings at the N85 location varied by less than $1 \mathrm{~cm} / \mathrm{h}^{1 / 2}$, whereas the $A$ parameter varied by less than $0.6 \mathrm{~cm} / \mathrm{h}$ (table 4$)$. Tre divergence of the cumulative-infiltration curves observed in the data (fig. 3) is reflected by the different values of $S$ and $A$. At N14, the $S$ and $A$ parameters were considerably different from those obtained at N85 (table 4).

Saturated hydraulic conductivity values extrapolated from the infiltration-rate curves between the tro

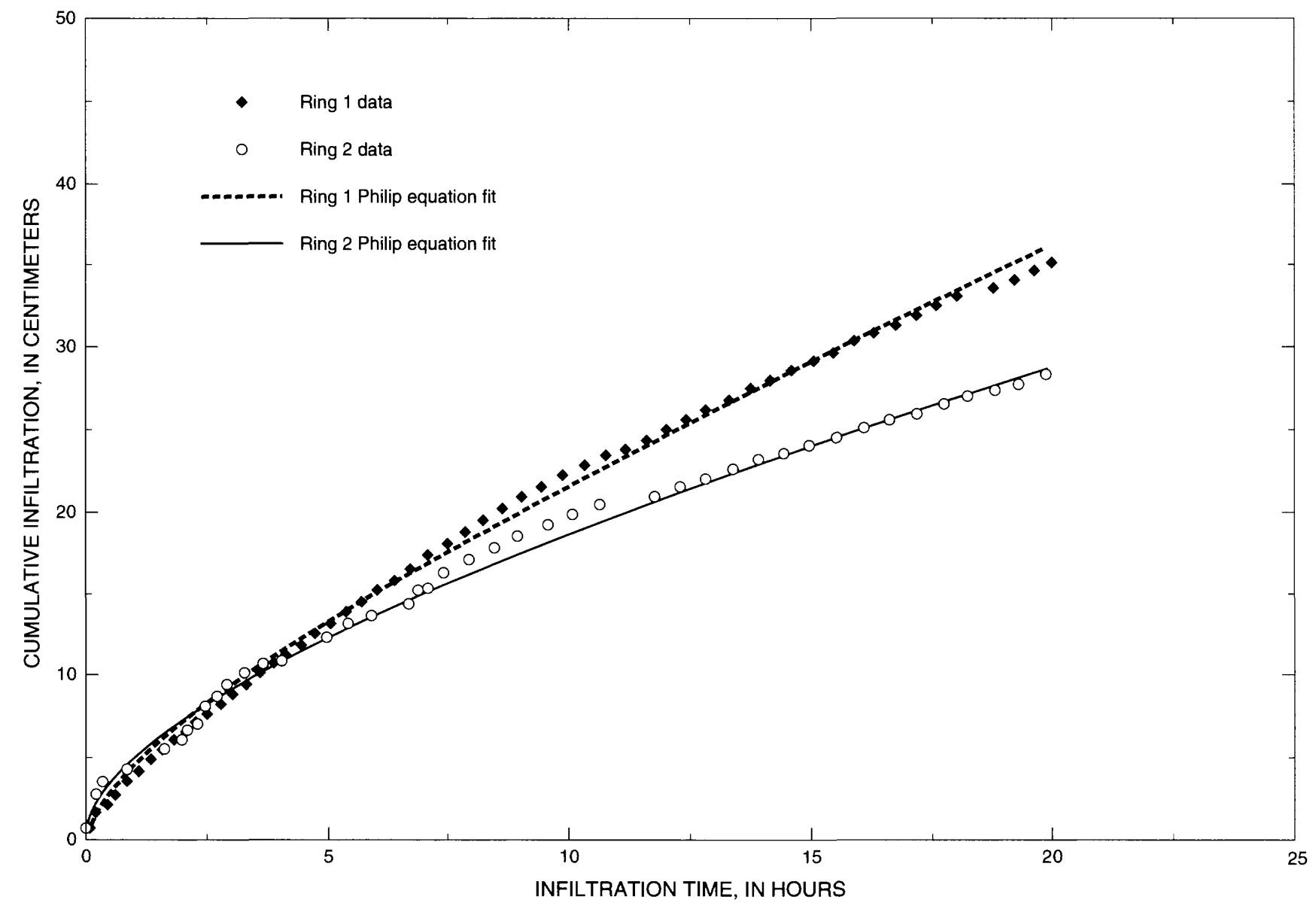

Figure 3. Cumulative-infiltration data and Philip-equation fit obtained near borehole UE-25 UZN \#85, Yucca Mountain, Nevada. 
Table 3. Cumulative-infiltration and infiltration-rate data using the automated prototype infiltrometer

\begin{tabular}{|c|c|c|c|}
\hline Ring location & $\begin{array}{l}\text { Infiltration time } \\
\text { (hours) }\end{array}$ & $\begin{array}{l}\text { Cumulative infiltration } \\
\text { (centimeters) }\end{array}$ & $\begin{array}{c}\text { Infiltration rate } \\
\text { (centimeters per hour) }\end{array}$ \\
\hline UE-25 UZN \#85 & 0.07 & 0.7 & 10.1 \\
\hline \multirow[t]{24}{*}{ Ring 1} & 0.19 & 1.7 & 8.8 \\
\hline & 0.46 & 2.1 & 4.6 \\
\hline & 0.60 & 2.7 & 4.5 \\
\hline & 0.84 & 3.6 & 4.3 \\
\hline & 1.09 & 4.2 & 3.9 \\
\hline & 1.34 & 4.9 & 3.6 \\
\hline & 1.58 & 5.5 & 3.5 \\
\hline & 1.82 & 6.1 & 3.3 \\
\hline & 2.08 & 6.6 & 3.2 \\
\hline & 2.28 & 7.1 & 3.1 \\
\hline & 2.52 & 7.6 & 3.0 \\
\hline & 2.77 & 8.3 & 3.0 \\
\hline & 3.04 & 8.9 & 2.9 \\
\hline & 3.32 & 9.5 & 2.9 \\
\hline & 3.59 & 10.1 & 2.8 \\
\hline & 3.88 & 10.7 & 2.8 \\
\hline & 4.13 & 11.3 & 2.7 \\
\hline & 4.44 & 11.8 & 2.7 \\
\hline & 4.74 & 12.5 & 2.6 \\
\hline & 5.05 & 13.2 & 2.6 \\
\hline & 5.37 & 13.9 & 2.6 \\
\hline & 5.70 & 14.5 & 2.5 \\
\hline & 6.04 & 15.2 & 2.5 \\
\hline & 6.38 & 15.8 & 2.5 \\
\hline UE-25 UZN \#85 & 6.73 & 16.5 & 2.5 \\
\hline \multirow[t]{21}{*}{ Ring 1} & 7.09 & 17.3 & 2.4 \\
\hline & 7.46 & 18.0 & 2.4 \\
\hline & 7.84 & 18.8 & 2.4 \\
\hline & 8.21 & 19.6 & 2.4 \\
\hline & 8.62 & 20.2 & 2.3 \\
\hline & 9.01 & 20.9 & 2.3 \\
\hline & 9.44 & 21.6 & 2.3 \\
\hline & 9.86 & 22.2 & 2.3 \\
\hline & 10.32 & 22.8 & 2.2 \\
\hline & 10.75 & 23.4 & 2.2 \\
\hline & 11.17 & 23.8 & 2.1 \\
\hline & 11.60 & 24.4 & 2.1 \\
\hline & 12.00 & 25.0 & 2.1 \\
\hline & 12.41 & 25.6 & 2.1 \\
\hline & 12.84 & 26.2 & 2.0 \\
\hline & 13.30 & 26.9 & 2.0 \\
\hline & 13.76 & 27.5 & 2.0 \\
\hline & 14.16 & 28.0 & 2.0 \\
\hline & 14.60 & 28.6 & 2.0 \\
\hline & 15.05 & 29.2 & 1.9 \\
\hline & 15.46 & 29.7 & 1.9 \\
\hline
\end{tabular}


Table 3. Cumulative-infiltration and infiltration-rate data using the automated prototype infiltrometer-Continued

\begin{tabular}{|c|c|c|c|}
\hline Ring location & $\begin{array}{c}\text { Infiltratlon time } \\
\text { (hours) }\end{array}$ & $\begin{array}{c}\text { Cumulative infiltration } \\
\text { (centimeters) }\end{array}$ & $\begin{array}{c}\text { Infiltration rate } \\
\text { (centimeters per hour) }\end{array}$ \\
\hline & 15.90 & 30.3 & 1.9 \\
\hline & 16.32 & 30.9 & 1.9 \\
\hline & 16.75 & 31.4 & 1.9 \\
\hline & 17.19 & 31.9 & 1.9 \\
\hline & 17.61 & 32.5 & 1.8 \\
\hline & 18.04 & 33.1 & 1.8 \\
\hline UE-25 UZN \#85 & 18.79 & 33.6 & 1.8 \\
\hline \multirow[t]{3}{*}{ Ring 1} & 19.21 & 34.1 & 1.8 \\
\hline & 19.64 & 34.7 & 1.8 \\
\hline & 20.00 & 35.1 & 1.8 \\
\hline UE-25 UZN \#85 & 0.05 & 0.6 & 12.3 \\
\hline \multirow[t]{22}{*}{ Ring 2} & 0.12 & 1.9 & 16.5 \\
\hline & 0.24 & 2.8 & 11.7 \\
\hline & 0.39 & 3.5 & 8.9 \\
\hline & 0.88 & 4.1 & 4.7 \\
\hline & 1.65 & 5.4 & 3.3 \\
\hline & 2.04 & 6.0 & 3.0 \\
\hline & 2.16 & 6.5 & 3.0 \\
\hline & 2.33 & 7.0 & 3.0 \\
\hline & 2.50 & 8.0 & 3.2 \\
\hline & 2.74 & 8.6 & 3.1 \\
\hline & 2.97 & 9.3 & 3.1 \\
\hline & 3.31 & 10.1 & 3.0 \\
\hline & 3.69 & 10.6 & 2.9 \\
\hline & 4.10 & 10.8 & 2.6 \\
\hline & 5.01 & 12.2 & 2.4 \\
\hline & 5.46 & 13.0 & 2.4 \\
\hline & 5.95 & 13.6 & 2.3 \\
\hline & 6.70 & 14.2 & 2.1 \\
\hline & 6.92 & 15.0 & 2.2 \\
\hline & 7.12 & 15.2 & 2.1 \\
\hline & 7.43 & 16.1 & 2.2 \\
\hline & 7.95 & 17.0 & 2.1 \\
\hline UE-25 UZN \#85 & 8.48 & 17.7 & 2.1 \\
\hline \multirow[t]{11}{*}{ Ring 2} & 8.99 & 18.4 & 2.1 \\
\hline & 9.59 & 19.1 & 2.0 \\
\hline & 10.13 & 19.7 & 1.9 \\
\hline & 10.69 & 20.3 & 1.9 \\
\hline & 11.81 & 20.9 & 1.8 \\
\hline & 12.34 & 21.4 & 1.7 \\
\hline & 12.85 & 21.9 & 1.7 \\
\hline & 13.41 & 22.5 & 1.7 \\
\hline & 13.94 & 23.0 & 1.7 \\
\hline & 14.46 & 23.5 & 1.6 \\
\hline & 15.03 & 23.9 & 1.6 \\
\hline
\end{tabular}


Table 3. Cumulative-infiltration and infiltration-rate data using the automated prototype infiltrometer-Continued

\begin{tabular}{|c|c|c|c|}
\hline Ring location & $\begin{array}{l}\text { Infiltration time } \\
\text { (hours) }\end{array}$ & $\begin{array}{l}\text { Cumulative infiltration } \\
\text { (centimeters) }\end{array}$ & $\begin{array}{c}\text { Infiltration rate } \\
\text { (centimeters per hour) }\end{array}$ \\
\hline & 15.57 & 24.4 & 1.6 \\
\hline & 16.13 & 25.0 & 1.5 \\
\hline & 16.68 & 25.5 & 1.5 \\
\hline & 17.22 & 25.9 & 1.5 \\
\hline & 17.81 & 26.4 & 1.5 \\
\hline & 18.27 & 26.9 & 1.5 \\
\hline & 18.85 & 27.2 & 1.4 \\
\hline & 19.34 & 27.6 & 1.4 \\
\hline & 19.90 & 28.2 & 1.4 \\
\hline \multirow[t]{6}{*}{ UE-25 UZN \#14 } & 0.0 & 0.0 & 0.0 \\
\hline & 0.03 & 2.3 & 67.9 \\
\hline & 0.05 & 2.8 & 56.6 \\
\hline & 0.07 & 3.4 & 51.4 \\
\hline & 0.10 & 4.7 & 47.1 \\
\hline & 0.12 & 4.8 & 41.4 \\
\hline \multirow[t]{28}{*}{ UE-25 UZN \#14 } & 0.13 & 5.2 & 39.0 \\
\hline & 0.15 & 6.2 & 41.2 \\
\hline & 0.17 & 8.2 & 49.2 \\
\hline & 0.20 & 8.7 & 43.3 \\
\hline & 0.22 & 7.8 & 35.8 \\
\hline & 0.25 & 8.1 & 32.3 \\
\hline & 0.27 & 9.0 & 33.7 \\
\hline & 0.28 & 9.4 & 33.3 \\
\hline & 0.32 & 9.2 & 29.1 \\
\hline & 0.33 & 10.0 & 30.1 \\
\hline & 0.35 & 10.2 & 29.2 \\
\hline & 0.38 & 12.0 & 31.2 \\
\hline & 0.40 & 13.1 & 32.7 \\
\hline & 0.42 & 12.1 & 29.1 \\
\hline & 0.45 & 12.1 & 26.8 \\
\hline & 0.47 & 11.0 & 23.5 \\
\hline & 0.48 & 12.9 & 26.7 \\
\hline & 0.52 & 13.1 & 25.4 \\
\hline & 0.53 & 14.2 & 26.7 \\
\hline & 0.57 & 14.5 & 25.6 \\
\hline & 0.58 & 15.2 & 26.0 \\
\hline & 0.60 & 14.8 & 24.6 \\
\hline & 0.63 & 12.3 & 19.4 \\
\hline & 0.65 & 12.0 & 18.5 \\
\hline & 0.68 & 15.5 & 22.7 \\
\hline & 0.70 & 17.7 & 25.3 \\
\hline & 0.72 & 18.6 & 26.0 \\
\hline & 0.75 & 20.7 & 27.6 \\
\hline \multirow[t]{2}{*}{ UE-25 UZN \#14 } & 0.77 & 21.0 & 27.3 \\
\hline & 0.80 & 20.7 & 25.8 \\
\hline
\end{tabular}


Table 3. Cumulative-infiltration and infiltration-rate data using the automated prototype infiltrometer-Continued

\begin{tabular}{|c|c|c|c|}
\hline Ring location & $\begin{array}{c}\text { Infiltration time } \\
\text { (hours) }\end{array}$ & $\begin{array}{l}\text { Cumulative infiltration } \\
\text { (centimeters) }\end{array}$ & $\begin{array}{c}\text { Inflitration rate } \\
\text { (centimeters per hour) }\end{array}$ \\
\hline & 0.82 & 20.1 & 24.7 \\
\hline & 0.85 & 21.4 & 25.1 \\
\hline & 0.87 & 21.2 & 24.4 \\
\hline & 0.88 & 20.0 & 22.6 \\
\hline & 0.92 & 19.6 & 21.4 \\
\hline & 0.93 & 20.8 & 22.3 \\
\hline & 0.97 & 22.0 & 22.7 \\
\hline & 0.98 & 23.2 & 23.6 \\
\hline & 1.00 & 22.7 & 22.7 \\
\hline & 1.03 & 23.5 & 22.8 \\
\hline & 1.05 & 21.9 & 20.8 \\
\hline & 1.07 & 21.8 & 20.4 \\
\hline & 1.10 & 22.1 & 20.1 \\
\hline & 1.12 & 22.3 & 20.0 \\
\hline & 1.13 & 23.5 & 20.7 \\
\hline & 1.17 & 23.5 & 20.2 \\
\hline & 1.18 & 24.6 & 20.7 \\
\hline & 1.20 & 25.2 & 21.0 \\
\hline & 1.23 & 26.0 & 21.1 \\
\hline & 1.25 & 26.9 & 21.5 \\
\hline & 1.27 & 27.5 & 21.7 \\
\hline & 1.30 & 26.6 & 20.4 \\
\hline & 1.32 & 26.5 & 20.1 \\
\hline & 1.33 & 26.9 & 20.2 \\
\hline & 1.37 & 28.2 & 20.6 \\
\hline & 1.38 & 28.9 & 20.9 \\
\hline \multirow[t]{20}{*}{ UE-25 UZN \#14 } & 1.40 & 28.5 & 20.4 \\
\hline & 1.42 & 28.5 & 20.1 \\
\hline & 1.45 & 28.9 & 19.9 \\
\hline & 1.47 & 28.3 & 19.3 \\
\hline & 1.48 & 28.4 & 19.1 \\
\hline & 1.50 & 30.9 & 20.6 \\
\hline & 1.53 & 32.8 & 21.4 \\
\hline & 1.55 & 34.5 & 22.2 \\
\hline & 1.57 & 33.5 & 21.4 \\
\hline & 1.60 & 34.5 & 21.6 \\
\hline & 1.62 & 33.3 & 20.6 \\
\hline & 1.63 & 33.3 & 20.3 \\
\hline & 1.67 & 34.8 & 20.9 \\
\hline & 1.68 & 33.3 & 19.8 \\
\hline & 1.72 & 34.1 & 19.9 \\
\hline & 1.73 & 35.0 & 20.2 \\
\hline & 1.77 & 35.6 & 20.1 \\
\hline & 1.78 & 36.4 & 20.4 \\
\hline & 1.82 & 34.7 & 19.1 \\
\hline & 1.83 & 35.9 & 19.6 \\
\hline
\end{tabular}


Table 3. Cumulative-infiltration and infiltration-rate data using the automated prototype infiltrometer-Continued

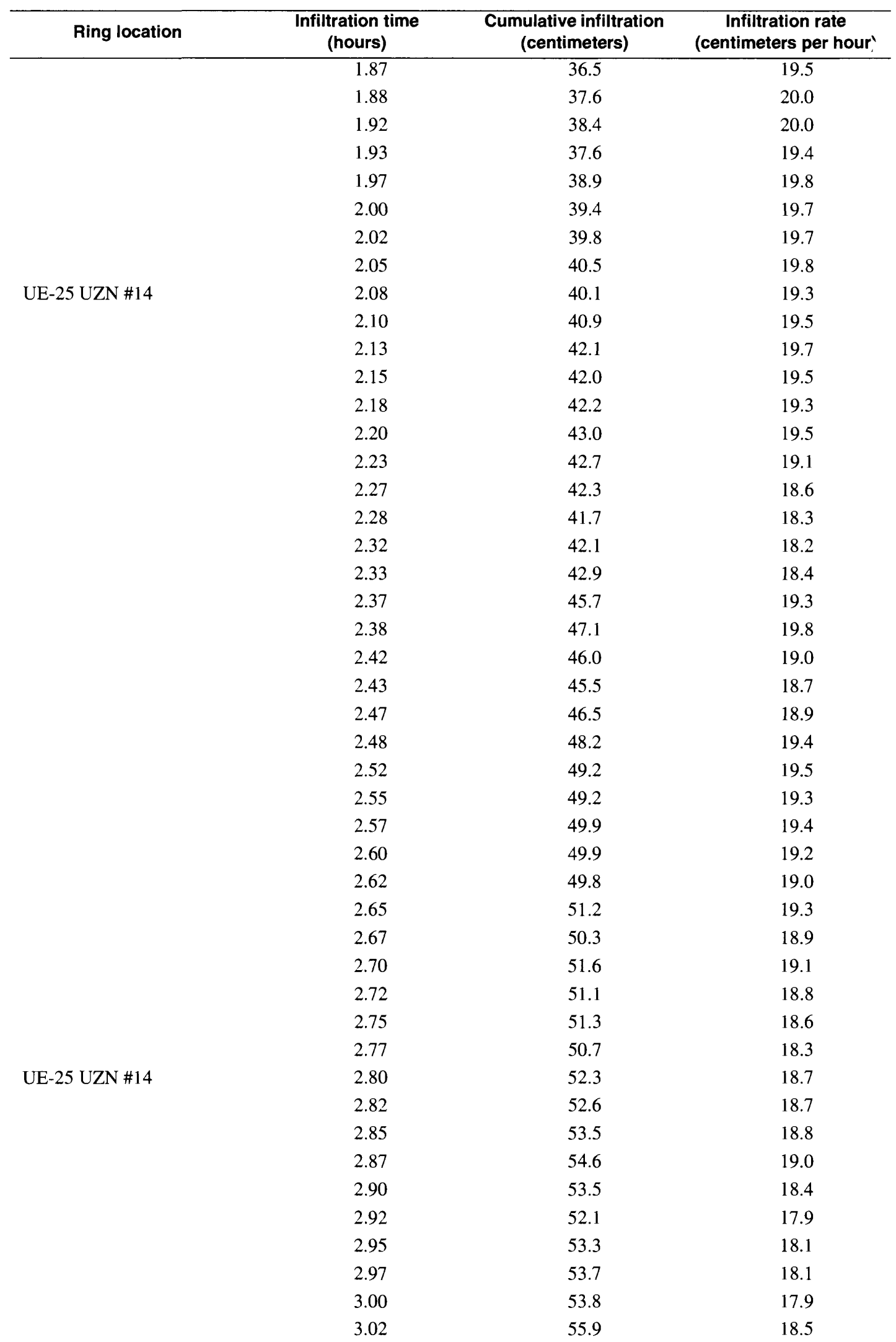


Table 3. Cumulative-infiltration and infiltration-rate data using the automated prototype infiltrometer-Continued

\begin{tabular}{|c|c|c|c|}
\hline Ring locatlon & $\begin{array}{c}\text { Infiltration time } \\
\text { (hours) }\end{array}$ & $\begin{array}{l}\text { Cumulative infiltration } \\
\text { (centimeters) }\end{array}$ & $\begin{array}{c}\text { Infiltration rate } \\
\text { (centlmeters per hour) }\end{array}$ \\
\hline & 3.05 & 56.8 & 18.6 \\
\hline & 3.07 & 55.7 & 18.1 \\
\hline & 3.10 & 54.8 & 17.7 \\
\hline & 3.12 & 55.4 & 17.8 \\
\hline & 3.15 & 56.4 & 17.9 \\
\hline & 3.18 & 56.7 & 17.8 \\
\hline & 3.20 & 57.6 & 18.0 \\
\hline & 3.23 & 58.4 & 18.0 \\
\hline & 3.25 & 57.3 & 17.6 \\
\hline & 3.28 & 58.4 & 17.8 \\
\hline & 3.30 & 59.2 & 17.9 \\
\hline & 3.33 & 60.7 & 18.2 \\
\hline & 3.37 & 60.3 & 17.9 \\
\hline & 3.38 & 60.9 & 18.0 \\
\hline & 3.42 & 60.7 & 17.8 \\
\hline & 3.43 & 60.0 & 17.5 \\
\hline & 3.47 & 62.2 & 17.9 \\
\hline & 3.48 & 62.6 & 18 \\
\hline \multirow[t]{21}{*}{ UE-25 UZN \#14 } & 3.52 & 62.8 & 17.9 \\
\hline & 3.53 & 62.8 & 17.8 \\
\hline & 3.57 & 63.9 & 17.9 \\
\hline & 3.58 & 63.2 & 17.6 \\
\hline & 3.62 & 65.1 & 18.0 \\
\hline & 3.63 & 65.6 & 18.1 \\
\hline & 3.67 & 65.6 & 17.9 \\
\hline & 3.68 & 64.9 & 17.6 \\
\hline & 3.70 & 64.4 & 17.4 \\
\hline & 3.73 & 64.7 & 17.3 \\
\hline & 3.75 & 64.9 & 17.3 \\
\hline & 3.78 & 67.3 & 17.8 \\
\hline & 3.80 & 67.9 & 17.9 \\
\hline & 3.82 & 66.8 & 17.5 \\
\hline & 3.85 & 67.0 & 17.4 \\
\hline & 3.87 & 67.5 & 17.4 \\
\hline & 3.90 & 69.2 & 17.7 \\
\hline & 3.92 & 69.7 & 17.8 \\
\hline & 3.95 & 70.1 & 17.7 \\
\hline & 3.97 & 70.5 & 17.8 \\
\hline & 3.98 & 71.7 & 18.0 \\
\hline
\end{tabular}




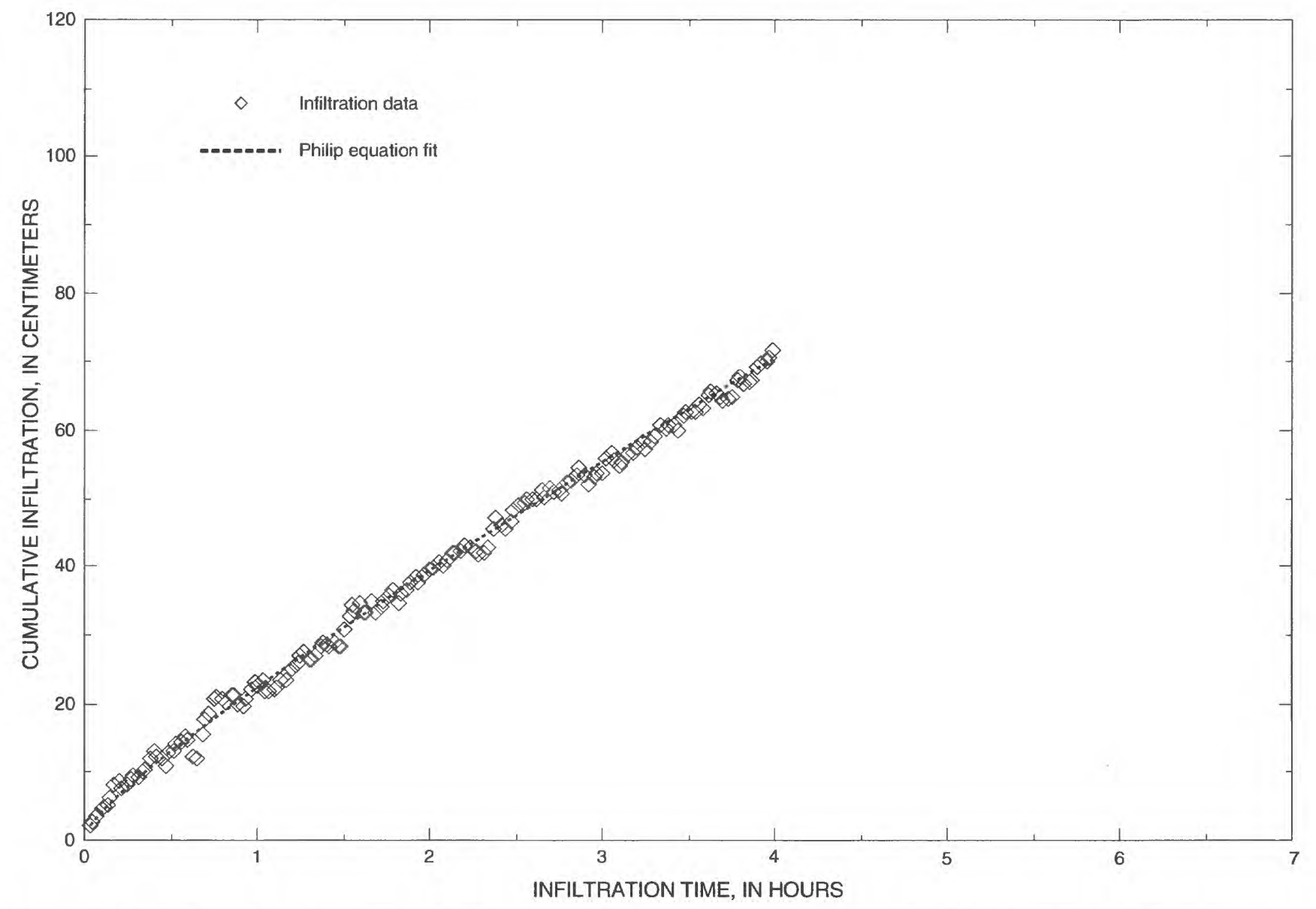

Figure 4. Cumulative-infiltration data and Philip-equation fit obtained near borehole UE-25 UZN \#14, Yucca Mountain, Nevada.

experiment sites differed by an order of magnitude (table 4). These differences in $K_{S}$ can be attributed to the different physical characteristics of the unconsolidated materials. Bulk densities of unconsolidated material averaged $1.89 \mathrm{~g} / \mathrm{cm}^{3}$ in the area of $\mathrm{N} 85$, whereas bulk densities averaged $1.41 \mathrm{~g} / \mathrm{cm}^{3}$ in the area of N14. Particle densities of unconsolidated materials on Yucca Mountain were fairly uniform; the measured average values were $2.54 \mathrm{~g} / \mathrm{cm}^{3}$. The differences in bulk densities between the two sites resulted in total porosities of 0.26 in the area of $\mathrm{N} 85$ and 0.44 in the area of N14. The larger porosities in the area of N14, in combination with little or no cementing of subsurface materials, may account for the differences in calculated hydraulic properties at the two sites. Differences in clay content (16 percent in the area of N85 compared to less than 4 percent in the area of N14) also may account for the differences in $S$ values.

The calculated infiltration rate (eq. 9) can be described numerically as the first derivative of cumu- lative infiltration compared to time (eq. 5). Infiltration rates near N85 and N14 were at or near steady-state within 1 to 2 hours after the start of ponding (figs. 5 and 6), although the model curve continued downward. The downward trend of the model curve is an artifact of using the Philip two-term equation rather than an expanded infinite-series solution of the equa-

Table 4. Calculated hydrologic parameters using the Philip two-term equation and corresponding experimentally extrapolated saturated hydraulic conductivity values

[All $S$ (sorptivity) measurements in centimeters per square root of hours; all $A$ and $K_{s}$ (saturated hydraulic conductivity) measurements in centimeters per hour]

\begin{tabular}{llcc}
\hline \multirow{2}{*}{ Location } & \multicolumn{3}{c}{ Philip-equation parameters } \\
\cline { 2 - 4 } & \multicolumn{1}{c}{$\boldsymbol{S}$} & \multicolumn{1}{c}{$\boldsymbol{A}$} & \multicolumn{1}{c}{$\boldsymbol{K}_{\boldsymbol{s}}$} \\
\hline UE-25 UZN \#85, Ring 1 & 3.73 & 0.98 & 1.78 \\
Ring 2 & 4.65 & 0.40 & 1.37 \\
UE-25 UZN \#14 & 9.40 & 12.94 & 17.79 \\
\hline
\end{tabular}


tion (Swartzendruber and Clague, 1989, p. 621). This is not a considerable artifact because $A$ is 0.3 to 0.6 times the value of $K_{S}$ and is not used to any great extent for further analysis.

Although the $S$ near N14 is more than twice as large as that at N85 (table 4), the differences are largely due to differences in $\theta_{i}$, because, as $\theta_{i}$ approaches saturation, $S(\theta)$ approaches 0 (Chong and Green, 1979, p. 92-93; Chong and others, 1982, p. 229). By estimating $S$ as a linear function of $\theta$, infiltration at different locations that have differing $\theta_{i}$ can be compared. To compare the different soils at different $\theta, \theta$ can be scaled as $\Theta=\theta / \theta_{s}$, where $\theta_{s}$ is water content at saturation and $\Theta$ is dimensionless soil-water content. The sorptivity-dimensionless soil- water characteristic curve is constructed as a linear function with $S=0$ at $\Theta=1$, crossing the measured point $\Theta_{i}$, the initial dimensionless water content, and extrapolating or interpolating for different values of $\Theta_{i}$. Initial soil-water contents were $0.15 \mathrm{~cm}^{3} / \mathrm{cm}^{3}(\Theta=$ $0.58)$ at $\mathrm{N} 85$ and $0.03 \mathrm{~cm}^{3} / \mathrm{cm}^{3}(\Theta=0.07)$ at $\mathrm{N} 14$. The larger initial soil-water contents at the N85 location could account for much of the $S$ differences between the two borehole locations. Further infiltration measurements made with differing $\theta_{i}$ are needed to determine if $S(\theta)$ for the unconsolidated materials covering Yucca Mountain has a linear relation.

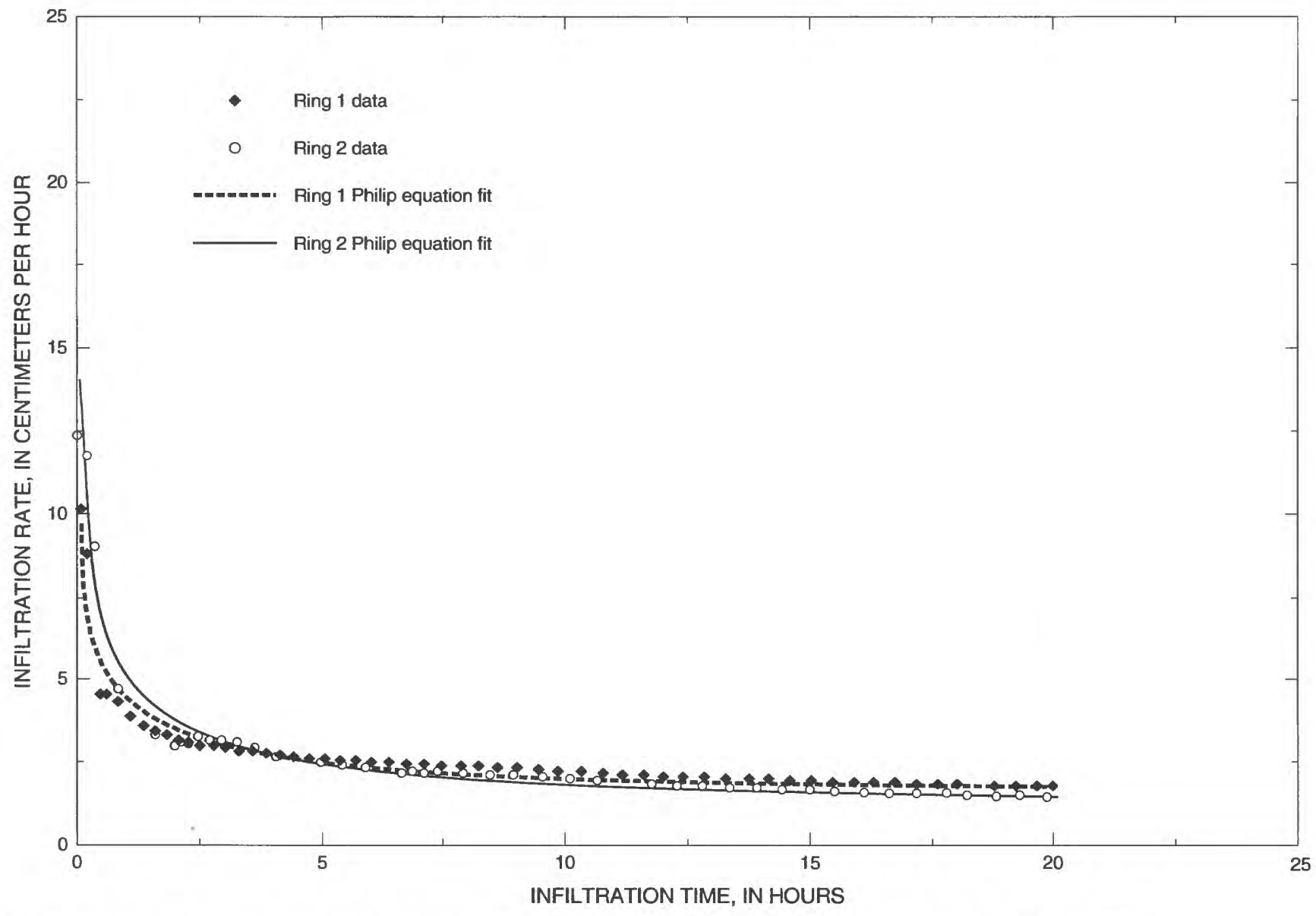

Figure 5. Infiltration-rate data and Philip-equation first derivative fit obtained near borehole UE-25 UZN \#85, Yucca Mountain, Nevada. 




Figure 6. Infiltration-rate data and Philip-equation first derivative fit obtained near borehole UE-25 UZN \#14, Yucca Mountain, Nevada.

\section{SUMMARY}

Hydrologic properties of the unconsolidated surficial materials covering Yucca Mountain are needed for interpretation of hydrologic data in the unsaturated zone and for input to hydrologic models. Two hydrologic properties, $K_{s}$ and $S$, were derived from cumulative-infiltration and infiltration-rate measurements of the unconsolidated materials. The Philip equation, which numerically describes the infiltration process, was used to calculate $K_{S}$ and $S$ using the infiltration measurements.

Infiltrometers designed to measure cumulative infiltration and infiltration rates were evaluated for their applicability and practicality for measuring $K_{s}$ and $S$ of Yucca Mountain unconsolidated materials. Because of the skeletal nature of the unconsolidated materials, the tension infiltrometer, sprinkler-imposed steady-flux infiltrometer, and ring infiltrometer were determined to be the best suited infiltrometers for measuring infiltration on Yucca Mountain. To obtain an understanding of the range in $K_{S}$ and $S$ at Yucca Mountain, an immediate priority was set to develop and test a fairly simple ring infiltrometer.

A prototype automated ring infiltrometer was developed to obtain reliable cumulative-infiltration and infiltration-rate data. Cumulative-infiltration and infiltration-rate curves were obtained at two borehole locations on Yucca Mountain. The infiltration experiments were conducted over time periods ranging from 4 to 20 hours, which was adequate to obtain a steadystate infiltration rate from which $K_{s}$ was extrapolated. Saturated hydraulic conductivity measurements differed by an order of magnitude between the two experiment sites.

The Philip two-term equation was used to calculate $S$ and the $A$ parameter related to $K_{s}$. Sorptivity measurements differed by more than 100 percent between the two experiment sites. The differences in $S$ could be attributed mainly to differences in initial soil- 
water contents at the experiment sites. Measured $K_{s}$ values were within theoretical constraints of the calculated Philip A parameter. A qualitative comparison between $K_{s}$ and $S$, and differences in measured physical characteristics of the surface materials, also helped explain infiltration differences between the two experiment sites. More infiltrometer measurements obtained at different initial soil-water contents and more detailed correlation studies between measured and derived hydrologic and physical properties of surface materials are needed to help understand infiltration capacities and variability on Yucca Mountain. The experiments helped define the methods needed to define selected hydrologic properties at Yucca Mountain.

\section{REFERENCES CITED}

Amoozegar, A., and Warrick, A.W., 1986, Hydraulic conductivity of saturated soils: Field methods, in Klute, A., ed., Methods of soil analysis-Physical and mineralogical methods, Part 1, (2d ed.): Madison, Wis., American Society of Agronomy, Agronomy 9 , p. 735-768.

Bouwer, Herman, 1966, Rapid field measurement of air entry value and hydraulic conductivity of soil as significant parameters in flow system analysis: Water Resources Research, v. 2, no. 4, p. 729-738.

Bouwer, Herman, 1986, Intake rate-Cylinder infiltrometer, in Klute, A., ed., Methods of soil analysis-Physical and mineralogical methods, Part 1, (2d ed.): Madison, Wis., American Society of Agronomy, Agronomy 9 , p. 825-844.

Chong, S.K., and Green, R.E., 1979, Application of fieldmeasured sorptivity for simplified infiltration prediction, in Proceedings of the symposium on hydrologic transport modeling-New Orleans, La., 1979: American Society of Agricultural Engineers Publication 4-80, p. 88-96.

Chong, S.K., Green, R.E., and Ahuja, L.R., 1982, Determination of sorptivity based on in-situ soil water redistribution measurements: Soil Science Society of America Journal, v. 46, no. 2, p. 228-230.

Clothier, B.E., and White, I., 1981, Measurement of sorptivity and soil water diffusivity in the field: Soil Science Society of America Journal, v. 45, no. 2, p. 241-245.
Elrick, D.E., and Reynolds, D.W., 1993, Measurement of saturated and near-saturated soil hydraulic conductivity, in Topp, G.C., Reynolds, W.D., and Green, R.E., eds., Advances in measurement of soil physical properties - Bringing theory into practice: Madison, Wis., Soil Science Society of America, Special Publication 30 , p. 1-24.

Flint, A.L., Flint, L.E., and Richards, K.A., 1994, Evaluation of measurement scale using imbibition experiments in volcanic tuffs: Soil Science Society of America Journal, v. 58, no. 1, p. 94-102.

Green, R.E., Ahuja, L.R., and Chong, S.K., 1986, Hydraulic conductivity, diffusivity, and sorptivity of unsaturated soils-Field methods, in Klute, A., ed., Methods of soil analysis-Physical and mineralogical methods, Part 1, (2d ed.): Madison, Wis., American Society of Agronomy, Agronomy 9, p. 771-798.

Hillel, Daniel, 1980, Applications of soil physics: New York, Academic Press, p. 5.

Hofmann, L.L., Guertal, W.G., Davies, W.J., and Flint, A.L., 1993, A large-scale, automated, constant-head, double-ring infiltrometer [abs.], in Agronomy Abstracts: Annual Meetings of the American Society of Agronomy, Crop Science Society of America, and Soil Science Society of America, November 7-12, Cincinnati, Ohio, 1993, p. 208.

Koorevaar, P., Menelik, G., and Dirksen, C., 1983, Elements of soil physics: New York, Elsevier, 228 p.

Logsdon. S.D., and Jaynes, D.B., 1993, Methodology for determining hydraulic conductivity with tension infiltrometers: Soil Science Society of America Journal, v. 57 , no. 6 , p. 1426-1431.

Perroux, K.M., and White, I., 1988, Designs of disc permeameters: Soil Science Society of America Journal, v. 52, no. 5, p. 1205-1215.

Philip, J.R., 1957, The theory of infiltration-4. Sorptivity and algebraic infiltration equations: Soil Science, v. 84 , p. 257-264.

Schmidt, M.R., Kolm, K.E., and Flint, A.L., 1992, Classification of upland soils by physical properties affecting infiltration in southern Nevada using the genesislithology-qualifier mapping system: Bulletin of the Association of Engineering Geologists, v. 29, no. 1, p. 33-47.

Scott, R.B., and Castellanos, M., 1984, Stratigraphic and structural relations of volcanic rocks in drill holes USW GU-3 and USW G-3, Yucca Mountain, Nye County, Nevada: U.S. Geological Survey Open-File Report 84-0491, p. 7-12.

Sharma, M.L., Gander, G.A., and Hunt, C.G., 1980, Spatial variability of infiltration in a watershed: Journal of Hydrology, v. 45, no. 1-2, p. 101-122. 
Swartzendruber, D., and Youngs, E.G., 1974, A comparison of physically-based infiltration equations: Soil Science, v. 117 , p. $165-167$.

Swartzendruber, D., and Clague, F.R., 1989, An inclusive infiltration equation for downward water entry into soil: Water Resources Research, v. 25, no. 4, p. 619626.

Talsma, T., 1969, In-situ measurement of sorptivity: Australian Journal of Soil Research, v. 7, p. 269-276.

Talsma, T., and Parlange, J.-Y., 1972, One-dimensional vertical infiltration: Australian Journal of Soil Research, v. 10, no. 2, p. 143-150.

U.S. Soil Conservation Service, 1975, Family and series differentiae and names, in Soil taxonomy- A basic system of soil classification for making and interpreting soil surveys: U.S. Department of Agriculture, Handbook 436, p. 383-405.

White, I., and Perroux, K.M., 1987, Use of sorptivity to determine field soil hydraulic properties: Soil Science Society of America Journal, v. 51, no. 5, p. 1093-1101.
White, I., and Perroux, K.M., 1989, Estimation of unsaturated hydraulic conductivity from field sorptivity measurements: Soil Science Society of America Journal, v. 53, no. 2, p. 324-329.

Wittwer, C.S., Bodvarsson, G.S., Chornack, M.P., Flint, A.L., Flint, L.E., Lewis, B.D., Spengler, R.W., and Rautman, C.A., 1992, Design of a three-dimensional site-scale model for the unsaturated zone at Yucca Mountain, Nevada, in High Level Radioactive Waste Management Conference; Proceedings of the third International conference: La Grange Park, Ill., American Nuclear Society, Inc., and American Society of Civil Engineers, p. 263-271.

Youngs, E.G., 1968, An estimation of sorptivity for infiltration studies from moisture moment considerations: Soil Science, v. 106, no. 3, p. 157-163.

Zimmerman, R.W., and Bodvarsson, G.S., 1989, An approximate solution for one-dimensional absorption in unsaturated porous media: Water Resources Research, v. 25 , no. 6, p. 1422-1428. 